\title{
MUNICIPALITIES AND THE SOLUTION OF EXPENDITURE IN THE PUBLIC INTEREST AND INDEBTEDNESS ${ }^{1}$
}

\author{
HANA MARKOVÁ2
}

\begin{abstract}
Municipalities as basic territorial self-governing units and regions as higher territorial self-governing units are considered to be the territorial self-governing units in the Czech Republic. They are public corporations which may have their own assets and manage according to their own budget. They are a part of the public sector and therefore they cannot be excluded from the budget management rules, including debt issues. An important fact is that they also receive funds collected from the central government, but their management is not burdened with the financing of mandatory expenditures to the extent it is with the state. Introducing the fiscal rules related to indebtedness is for ensuring budgetary discipline, to reduce the long-term deficit management financed from foreign resources and to strengthen co-responsibility for the development of public finances. The public interest and the level of indebtedness have an important role in deciding on the granting of state subsidies, which can take different forms.
\end{abstract}

\section{Keywords}

Municipality; budget; debt brake; subsidies

JEL Classification: H60, H63, H72

1 This paper has been elaborated within the programme "PROGRES Q02 - Publicization of Law in the European and International Context" which is realized in 2018 at the Faculty of Law of the Charles University.

2 Professor of Financial Law and Financial Science, Department of Financial Law and Financial Science, Faculty of Law, Charles University, Czech Republic. The Author specializes in tax law and insurance law. She is the author or co-author of more than 10 books and 70 reviewed articles. She is a member of Information and Organization Centre for the Research on the Public Finances and Tax Law in the Countries of Central and Eastern Europe. Orcid.org/0000-0002-0204-4571. Contact email: markova@prf.cuni.cz. 


\section{Introduction}

Municipalities as basic territorial self-governing units and regions as higher territorial self-governing units are considered to be the territorial self-governing units in the Czech Republic. According to the Constitution of the Czech Republic (Art. 101/3), they are public corporations which may have their own assets and manage according to their own budget. Municipalities and regions, therefore, have their own (separate) budgets that are not part of the State budget. They act under their own name, acquire assets and separately manage according to their own budget. The aim of the article is to analyze selected municipal expenditures in the public interest, in relation to the issue of indebtedness. In particular, the analytical and synthetic method will be used.

\section{Legal Status of Municipalities and their Budgets in the Czech Republic}

The constitutional concept of territorial self-governing units in the Czech Republic is based on the fact that municipalities and regions are public corporations, legal persons governed by the public law other than the State, separated even in the field of property rights. According to an explicit amendment of the law, the State is not responsible for the management and obligations of the municipality or the region, unless such an obligation is taken over by the State. The rules for the establishment of obligations of territorial self-governing units from loans, credits, and other titles, are governed by general rules of private law, but there are restrictions against the rules of private law:

- except for the exceptions allowed by law, it is the prohibition of the liability of territorial self-governing units for third-party obligations, under penalty of invalidity of a legal act which would infringe such a prohibition;

- general obligation to dispose with their assets effectively and efficiently, the obligation to take care of and control the management with the assets of the territorial self-governing units.

This means, for example, that the risk of incurring debts due to issued municipal bonds is limited by the legal requirement of the Ministry of Finance's prior approval to issue municipal bonds.

The budgets of municipalities and regions shall be approved by their authorities, namely the Municipal Council and the Regional Council. The budget of the territorial self-governing unit is compiled balanced, surplus or deficit. A deficit budget may be approved only if the deficit can be covered by funds from past years 
or by secured returnable sources, which according to the law means a contractually secured loan, credit, returnable financial assistance or income from the sale of municipal bonds. It is therefore in the public interest to make the expenditure of municipalities and regions do not exceed certain amounts - do not lead to debt and at the same time cover the need for the territory development.

However, in the case of the mismanagement or lack of responsibility, they can get into a situation where their right will be fundamentally limited by high liabilities and insolvency, that they will not be able to resolve their income and assets in the next few years. The consequence is that the territorial self-governing unit is not able to properly exercise self-government (the right of the territorial self-governing unit citizens is guaranteed by the Constitution). It is also essential for these reasons that certain rules of budgetary responsibility should apply to municipalities and regions.

\section{Rules of Budget Management - Debt Brake}

Municipalities and regions are part of the public sector ${ }^{3}$ and therefore cannot be excluded from the rules of budget management and debt issues. Equally important is the fact that they receive funds collected by the central government for their actions and that their management is not burdened with the financing of mandatory expenditures to the extent as it is in case of the State. The legislation stipulates three sets of obligations for the municipalities and regions (hereinafter territorial selfgoverning units, the TSU):

- approval of a balanced or surplus budget in the event of launching a debt brake (i.e. when the public-sector debt exceeds 55\% of GDP);

- the gradual reduction of the old debts of TSU, in the case, that the current debt exceeds $60 \%$ of the average income for the past 4 years (fiscal rule);

- the publication of data relating to the budget and management.

Rule of the debt brake, which is contained in the Act on Budgetary Responsibility, stipulates that if the debt of public institutions sectors amounts to at least $55 \%$ of nominal GDP, the TSU must approve their budget for the following year as balanced or in surplus. However, this restriction is not absolute and there are exceptions out of it. The budget can be established as deficit if the shortfall can be paid:

1. through money saved from previous years,

3 The public sector institutions is composed of approx. 17,500 entities. They are organizational units of the State, municipalities, state contributory organizations, voluntary associations of municipalities, public research institutions, regions, health insurance companies, legal persons established for the purpose of satisfying needs of public interest, the founder of which is a public institution: financed by a public institution or governed by a public institution (ability to enforce managers' appointment/dismissal), contributory organizations established by the TSU, regional councils, state funds. 
2. through returnable financial assistance;

3. through credit, a loan or the income from the sale of municipal bonds, if these funds are to be used for the pre-financing of projects supported by the EU budget.

Income forms - to put it simply - the sum of all consolidated cash performances received in the budget during the calendar year, and the debt of the TSU consists of unpaid liabilities from issued bonds, borrowings, loans and returnable financial assistance; execution of fulfillment from guarantees, issued promissory notes.

A fiscal rule is introduced by law in order to ensure a budgetary discipline in case of the TSU, to reduce long-term deficit management that is financed from foreign sources and to strengthen co-responsibility for the development of public finances that states following:

a) the amount of the debt should not exceed $60 \%$ of the total income of TSU and if this limit is exceeded,

b) the TSU has an obligation to gradually repay the previous debt at least of 5\% from the difference between the amount of the debt and $60 \%$ of the average income. $^{4}$

The objective of the given fiscal rule is to ensure budgetary discipline in case of the TSU, to reduce the long-term deficit management that is financed from foreign resources and to strengthen co-responsibility for the development of public finances. If the TSU will not repay its debts at least within the limits mentioned, a part of the tax revenues (shared taxes) that will be kept in the special account and will be released for repayment of the previous obligations of the TSU, will be detained. The established fiscal rule leaves considerable leeway to the territorial self-governing units in their management and defines the only debt capacity that is generally considered to be "safe". At the same time, the predictability of public sector indebtedness development is increased through it. ${ }^{5}$

\section{Subsidies - their Structure and Role in Safeguarding the Public Interest}

Subsidies form a significant income of regions and municipalities - either from the State budget or State funds or, in the case of municipalities, the subsidies are from

\footnotetext{
The value of the rule is calculated as the total income calculated as the average for the previous 4 years. At present, roughly 500 municipalities exceed the level of the fiscal rule, while most of them have debts up to their one annual budget. In more than $84 \%$ of the concerned municipalities, the minimum amount of the debt repayment forms less than $5 \%$ of their total income. Almost $80 \%$ of the municipalities for which the minimum amount of the debt repayment exceeds $10 \%$, it is able to finance the income shortfall through balances in their accounts (Matej, 2017).
} 
the budget of regions. One of the criteria used by the providers of subsidies from the State budget and from State funds towards the municipalities is, whether the provision of those resources is in the public interest and therefore, their indebtedness is also investigated. This criterion, however, does not mean the automatic loss of the municipalities' possibility to obtain State subsidy, is the only one of the conditions for deciding on the granting of State subsidies to the municipality, which should be taken into account by providers of subsidies. For this criterion, however, a subjective assessment will not be avoided and the individual departments do not take the given indicator into the consideration in the same way and with the same degree of seriousness. In deciding whether to grant a subsidy, the potential increase in indebtedness due to ensuring the co-financing of the municipality and the region in participating in EU funded programs should also be taken into consideration. However, the subsidies can also be found on the expenditure side of budgets of municipalities, which provide them to different entities, and therefore their nature and impact on the public in a given location should be respected.

The municipality acts as a public authority in the subsidy's provision. The municipality concludes a subsidy grant contract with the recipient of the subsidy, but can unilaterally interfere with the rights and obligations, may cut or totally revoke the subsidy (by administrative decision), impose levies for violating budgetary discipline. The municipality thus has more control over the handling of money.

The provision of subsidies is implemented through public service contracts in the Czech Republic. Although it is designated as the contract, it is not a typical contract according to the Civil Code, but it is based on rights and obligations in the field of public law. By concluding a contract, the subsidy recipient is entitled to receive the subsidy (only after the conclusion of the contract, there is no legal claim to subsidy before the conclusion) and the obligation to use the subsidy for the specified purpose, submit the bill and subject to control and, where appropriate, sanctions. On the one hand, the municipalities are also obliged to pay the subsidy and, on the other hand, the right to control the recipient and, where appropriate, to impose sanctions and levies. The provision of subsidies must be approved by a separate resolution of the authority of the municipality - it is not possible to approve the subsidy only as part of the dealt budget. Any appeal or other legal remedies are admissible against the decision on the failure to provide subsidies, however, it is generally possible to oppose it in court. However, the Court does not have the power to determine how the municipality will handle its assets, so the review of this decision will be very limited.

Criteria for objective and fair distribution system of budget funds of the municipalities should, therefore, respect certain requirements (Peková, 2004: 299): 
- it should be easily identifiable at a given time in each municipality;

- it should be objectively pronounced in easily measurable units;

- it should not be sensitive to the influence of local politics;

- it should not be too dependent on cyclical changes;

- it should take objective changes in time into account;

- it should be fixed at a certain time so that municipalities can plan their level in the medium-term budget forecast;

- it should not be too detailed so that a set of criteria was too extensive and thus difficult to control. Their use should be associated with the lowest administrative costs.

In the Act on Budgetary Rules which concern municipalities and regions as providers, there are two types of subsidies that municipalities can provide - the program subsidy and the individual subsidy.

Program subsidy is paid on the basis of the program - a sort of public communication that the municipality is interested in promoting a specific area, there is a public interest, and applicants can turn to the municipality with their applications. The program, announced by the municipality, must include the elements listed in the law, which means that not everything that was or is marked as the program, is the title which can be marked as the program under the Act on Budgetary Rules of Territorial Budgets.

In addition to the program subsidies, there are individual subsidies, which will be provided by the municipality on the basis of individual applications - the subsidies cannot be provided to unilaterally or only on the initiative of the municipality. Someone must always submit an application which must comply with the formalities - if the application does not contain these elements, it cannot be complied with, but nothing precludes the municipality from requesting the applicant to the supplement, of course.

The subsidies provided to the budget of the municipality or region may be of a demanding or non-demanding nature. The State, using demanding subsidies, tries to ensure that goods and services, which, in particular, municipalities provide on the basis of their delegated powers and to guarantee a certain standard level of certain public services. The path of these subsidies thus allows the State to check the economy and the public interest or purpose for the spending of funds on the part of the recipients. Demanding subsidies from the National budget must be provided to the municipalities by law. Thus, unlike non-demanding subsidies, they are stable and permanent income to the municipality budget. In terms of funding should be allocated to municipalities all the costs associated with the exercise of devolved 
government. Services that a municipality provides delegated scope, however, they are also often performed for the residents of other municipalities. The problem is that municipalities are not adequately compensated for the exercise of delegated powers, and so the municipality loses some of their revenues that could be used for their development. The size of the State contribution to the budget of the municipalities should be based on the objective costs of the activity concerned.

Another problem circuit in the area of the demanding subsidies constitutes subsidies on the devices, for which is the founder the municipality, but whose services are provided to the mainstream territory (subsidies to the social care institutions, retirement homes, selected medical facilities). The subsidy object here is one place, and here it is shown that the provided subsidy does not cover the total costs of municipalities for these facilities. The municipality through a provided subsidy must provide part of the funds from its own resources. In the case that in such facilities, the residents of other municipalities are located, there is not much addressing the question of the settlement between municipalities.

The subsidies for social benefits (transfer of the funds for social benefits) are associated with the devolved government powers to municipalities in relation to the payment of social benefits. These subsidies fully cover municipality payments for social benefits. The non-demanding subsidies (www.denik.obce.cz) are the second part of the subsidies that municipalities can receive from the State, but about which they must bid for the authorities of the State. Obtaining these resources depends on a number of circumstances - the volume of the resources of the State, the number of own resources of the municipality, the amount of the requirements, a debt of municipalities, regional policy of the State, but also likely non-transparent allocation, lobbying, corruption, etc.

\section{Conclusions}

It can be summarized that subsidies are the State-supported activities of the municipalities, which are mostly of an investment character, meeting the public interest. They are provided through State-announced programs. The reason for the existence of the non-demanding subsidies should not be only the compensation to the low level of tax revenue of some municipal budgets and their uneven distribution between the individual size categories of municipalities. The State should ensure that there is greater transparency and also control of their use. Public control would not apply to providers of subsidies only, but also on the recipient. In fact, the application gives very hard verifiable data and the subsidy proceedings are sometimes opaque. 
The area of legislating the provision of subsidies is undergoing dynamic development and it can be expected that in the nearest future additional rules will be adopted, which will complement the existing Act on Budgetary Rules.

\section{References}

Kopecký, M., Suchánek R.: The budgeting process and issues of indebtedness in the Czech Republic, The Lawyer Quarterly no. 2 (2014).

Marková, H.: Dotace, municipality a zneužití práva (Subsidies, municipalities and abuse of rights), in: Mrkývka, P., Pařízková I., Valdhans, J. (eds.): Zneužití práva a svévole při veřejné finanční činnosti (Abuse of law and arbitrariness in public financial activity), Brno: Masarykova Univerzita, 2015.

Matej, M.: Pravidla rozpočtové odpovědnosti v podmínkách obcí a krajů (Rules of Budget Responsibility in the Context of Municipalities and Regions), Obec a finance (Municipality and Finance) no. 1 (2017).

Peková, J.: Hospodaření a finance územní samosprávy (The Management and Finances of the Territorial Self-Government), Praha: Management Press, 2004.

Role dotací v územních rozpočtech (The role of subsidies in local budgets), 2012. www.denik.obce.cz.

CZ: Act no. 250/2000 on Budgetary Rules of Territorial Budgets, as amended.

CZ: Act no. 23/2017 on Budgetary Responsibility Rules. 